\title{
CONCLUDING OBSERVATIONS OF THE UN HUMAN RIGHTS TREATY BODIES IN THE FIELD OF EQUALITY AND NON-DISCRIMINATION. DOES A COMMON STANDARD EXIST AND IS IT IMPLEMENTED? EXAMPLE OF POLAND
}

\begin{abstract}
This article examines the recommendations adopted by UN human rights treaty bodies in 2000-2017 addressed to Poland and concerning equality and non-discrimination. It aims to answer two research questions - firstly, to what extent are the recommendations convergent and, therefore, can we speak of a certain common standard of equality and non-discrimination formulated by treaty bodies? For this purpose, two case studies - on LGBT rights and women's reproductive rights - have been presented. The second part of the research aims to establish to what extent do the recommendations of treaty bodies on equality and nondiscrimination affect Polish law.
\end{abstract}

Keywords: equality, human rights, LGBT rights, non-discrimination, Polish law, reproductive rights, UN standards

* Ph.D., Institute of Law Studies of the Polish Academy of Sciences, Warsaw, k.sekowska-kozlowska@inp.pan.pl 


\section{Introduction ${ }^{1}$}

The UN system of human rights protection based on the work of treaty bodies has a complex structure. Presently, there are ten committees composed of independent experts, which periodically monitor the implementation of treaty obligations by States-parties to the specific treaties. The reporting procedure is the main control mechanism and the concluding observations, i.e. decisions addressed by the committees to States-parties are its "final product". They include evaluation of the implementation of the rights contained in individual treaties and recommendations of actions aimed at the implementation of the obligations assumed by the States.

The abundant collection of UN conventions built over the past few a few decades contains both treaties, which are overviews of catalogues of rights and freedoms, as well as treaties on the rights of selected groups or those focused on particular problems. This means that some of the convention obligations are duplicated. Undoubtedly, regulations related to the principle of equality and non-discrimination ${ }^{2}$ in the enjoyment of human rights and freedoms, which were formulated in the majority of the treaties, are one such group. Each of the bodies which monitor observance of a given treaty produces its autonomous interpretation. A question arises as to whether assessments made by individual treaty bodies and, consequently, their recommendations are convergent? ${ }^{3}$ Can we speak of a certain type of a "common standard" formulated by such bodies? In this article, an attempt has been made to answer this question based on selected recommendations addressed to Poland and related to equality and non-discrimination.

The second part of the article relates to the implementation of treaty bodies' recommendations by Poland. The research focus on recommendations pertaining to Polish law and the legal steps postulated by the committees

1 The article presents results of research funded by the National Science Centre under project No. 2012/07/B/HS5/03727.

This research is based on the assumption that "equality and non-discrimination are positive and negative statements of the same principle”, A. Bayefsky, The Principle of Equality or Non-Discrimination in International Law, 'Human Rights Quarterly' 1990, no 1-2, p. 1.

3 For general study in this subject, see W. Vandenhole, Non-Discrimination and Equality in the View of the UN Human Rights Treaty Bodies, Intersentia, Antwerpen-Oxford 2005. 
to implement the principle of equality and non-discrimination. It aims to reveal the areas of Polish law in which treaty bodies have identified the greatest deficits, as well as the extent to which their recommendations have been implemented. The results may contribute to global academic research on the domestic impact of the reporting process under UN human rights treaties ${ }^{4}$.

\section{Scope and methodology}

Poland is party to the core UN human rights treaties which include antidiscrimination regulations. These are:

- The International Convention on the Elimination of All Forms of Racial Discrimination (ICERD), monitored by the Committee on the Elimination of Racial Discrimination (CERD);

- The International Covenant on Civil and Political Rights (ICCPR), monitored by the Human Rights Committee (HRC);

- The International Covenant on Economic, Social and Cultural Rights (ICESCR), monitored by the Committee on Economic, Social and Cultural Rights (CESCR);

- The Convention on the Elimination of All Forms of Discrimination against Women (CEDAW Convention), monitored by the Committee on the Elimination of Discrimination against Women (CEDAW);

- The Convention on the Rights of the Child (CRC Convention), monitored by the Committee on the Rights of the Child (CRC);

- The International Convention on the Rights of Persons with Disabilities (CRPD Convention), monitored by the Committee on the Rights of Persons with Disabilities (CRPD).

The studies comprised the concluding observations addressed to Poland in 2000-2017 by the committees which monitor implementation

4 E.g. J. Krommendijk, The (In)effectiveness of UN Human Rights Treaty Body Recommendations, 'Netherlands Quarterly of Human Rights' 2015, no 2, p. 195, for earlier research in this subject, see for example, Ch. Heyns and F. Viljoen, The Impact of the United Nations Human Rights Treaties on the Domestic Level, Martinus Nijhoff Publishers, The Hague-London, 2002. 
of the treaties ${ }^{5}$. The analysis also included the concluding observations made by the Committee against Torture (CAT), which monitors implementation of the Convention against Torture and Other Cruel, Inhuman or Degrading Treatment (CAT Convention). Although there are no anti-discriminatory regulations in the treaty, this body, within the framework of its mandate, also formulates recommendations combining the problems of equality and non-discrimination, which will be explained in the subsequent part of this article.

In total, sixteen concluding observations have been analysed. They were adopted and addressed to Poland by the following bodies:

- CERD: in $2003^{6}, 2009^{7}, 2014^{8}$

- CEDAW: in $2007^{9}, 2014^{10}$

- HRC: in $2004^{11}, 2010^{12}, 2017^{13}$

- CESCR: in $2002^{14}, 2009^{15}, 2016^{16}$

5 During the preparation of this article, examination of the first report of Poland on the implementation of CRPD Convention submitted to CRPD was still pending, and therefore the work of this body was excluded from the study.

${ }^{6}$ Concluding observations of the Committee on the Elimination of Racial Discrimination regarding Poland, 2.6.2003, CERD/C/62/CO/6, hereinafter: CERD 2003.

7 Concluding observations of the Committee on the Elimination of Racial Discrimination regarding Poland, 14.9.2009, CERD/C/POL/CO/19, hereinafter: CERD 2009.

8 Concluding observations of the Committee on the Elimination of Racial Discrimination regarding Poland, 19.3.2014, CERD/C/POL/CO/20-21, hereinafter: CERD 2014.

9 Concluding observations of the Committee on the Elimination of Discrimination against Women regarding Poland, 2.2.2007, CEDAW/C/POL/CO/6, hereinafter: CEDAW 2007.

10 Concluding observations of the Committee on the Elimination of Discrimination against Women regarding Poland, 14.11.2014, CEDAW/C/POL/CO/7-8, hereinafter: CEDAW 2014.

11 Concluding observations of the Human Rights Committee regarding Poland, 2.12.2004, CCPR/CO/82/POL, hereinafter: HRC 2004.

12 Concluding observations of the Human Rights Committee regarding Poland, 15.11.2010, CCPR/C/POL/CO/6, hereinafter: HRC 2010.

13 Concluding observations of the Human Rights Committee regarding Poland, 23.11.2017, CCPR/C/POL/CO/7, hereinafter: HRC 2017.

14 Concluding observations of the the Committee on Economic, Social and Cultural Rights regarding Poland,19.12.2002, E/C.12/1/Add.82, hereinafter: CESCR 2002.

15 Concluding observations of the the Committee on Economic, Social and Cultural Rights regarding Poland, 2.12.2009, E/C.12/POL/CO/5, hereinafter: CESCR 2009.

${ }_{16}$ Concluding observations of the the Committee on Economic, Social and Cultural Rights regarding Poland, 26.10.2016, E/C.12/POL/CO/6, hereinafter: CESCR 2016. 
- CRC: in $2002^{17}, 2015^{18}$

- CAT: in $2000^{19}, 2007^{20}, 2013^{21}$

The first phase of the analysis comprised identification of all concluding observations related to the problems of equality and nondiscrimination. In the case of CERD and CEDAW, i.e. bodies which monitor conventions of a strict anti-discrimination nature, the analysis comprises all the recommendations formulated in their concluding observations. In the case of the other bodies, recommendations related to the problems in question were identified. Two selection criteria were adopted. Firstly, recommendations related directly to anti-discrimination regulations contained in a given treaty were selected. They included: Article 2 para. 1, Article 3 and Article 26 ICCPR, Article 2 para. 2 and Article 3 ICESCR and Article 2 para. 1 CRC Convention. Secondly, recommendations which pertained to other treaty regulations were selected when their aim was to ensure selected rights and freedoms for the persons who belonged to the groups discriminated against (e.g. women, LGBT persons, persons belonging to ethnic minorities).

The second phase of the analysis was aimed at determining the extent to which the recommendations made by individual bodies are convergent. To that end, two groups of recommendations were identified, namely recommendations related to the rights of LGBT persons and recommendations related to the protection of women's reproductive health. These particular recommendations were selected for two reasons. Firstly, these problems were the subject of the concluding observations formulated by the majority of the treaty bodies examined, which provides sufficient data for analysis. Secondly, both the protection of the rights of LGBT persons

17 Concluding observations of the Committee on the Rights of the Child regarding Poland, 30.10.2002, CRC/C/15/Add.194, hereinafter: CRC 2002.

18 Concluding observations of the Committee on the Rights of the Child regarding Poland CRC/C/POL/CO/3-4, 2.10.2015, hereinafter: CRC 2015.

19 Concluding observations of the Committee against Torture regarding Poland, 5.5.2000, A/55/44, hereinafter: CAT 2000.

20 Concluding observations of the Committee against Torture regarding Poland, 25.7.2007, CAT/C/POL/CO/4, hereinafter: CAT 2007.

21 Concluding observations of the Committee against Torture regarding Poland, 23.12.2013, CAT/C/POL/CO/5-6, hereinafter: CAT 2013. 
and women's reproductive rights continue to stir numerous controversies and contain obstacles on a national level ${ }^{22}$.

Therefore, it was worthwhile to determine whether in the case of treaty bodies we can speak of a certain "common standard" and similar interpretation of treaty obligations. To this end, individual recommendations were identified from the entire material studied and were followed by the verification of which bodies included them and when in their concluding observations. The results have been presented in the second part of the article.

The third phase of the analysis related to the implementation of treaty bodies' recommendations. First, a working classification of recommendation types has been introduced. Secondly, recommendations related to the legal situation, i.e. legislative steps taken to implement new legal instruments or amend the existing law, were selected. Comparison of the present status of Polish law with the recommendations of the treaty bodies led to determination of how many of the recommendations have been implemented. The results have been presented in the third part of the article.

\section{In search of a common standard - selected examples}

\subsection{Case study 1. LGBT rights}

International agreements, on which the work of the treaty bodies analysed here is based, do not contain any direct reference to LGBT rights. In ICCPR and ICESCR, prohibition of discrimination on grounds of sexual orientation and gender identity results from the general prohibition of discrimination formulated in Article 2 para. 1 ICCPR and Article 2 para. 2 ICESCR, in which States-parties have committed to ensure that the rights contained in a given treaty can be enjoyed without any discrimination on the grounds

22 More on reproductive rights in Poland, see for example J.D. Caytas, Women's Reproductive Rights as a Political Price of Post-communist Transformation in Poland, 'Amsterdam Law Forum' 2013, no. 2, more on LGBT rights in Poland, see for example Z. Warso and A. Bodnar 'Legal Study on Homophobia and Discrimination on Grounds of Sexual Orientation and Gender Identity. Poland. January 2014 Update' FRA Country Report, http:// fra.europa.eu/sites/default/files/fra_uploads/country-study-lgbt-legal-update-2014-pl. pdf [last accessed 23.3.2016]. 
mentioned in these articles, such as sex or race or "other status" ${ }^{23}$. In the breakthrough case of Toonen v. Australia (1994), HRC stated that sexual orientation is a protected status in ICCPR ${ }^{24}$. Likewise, over the last few decades in CESCR practice, sexual orientation and gender identity have been recognised as characteristics legally protected against discrimination ${ }^{25}$. CRC formulates the open anti-discrimination clause in a similar manner, prohibiting discrimination on the grounds of "other status" of a child and a child's parent/guardian (Article 2 para. 1). The CRC Committee, in the same period as HRC and CESCR, adopted general comments stating that sexual orientation and gender identity are characteristics legally protected by $C R C$ under Article $2^{26}$.

CEDAW and CAT address the protection of LGBT persons through the prism of the specific character of the conventions which they monitor. CEDAW examines the problems, in particular, in the context of intersectional discrimination and states that discrimination of women on the grounds of sex is often inseparably connected with other grounds, such as sexual orientation and gender identity, age or disability ${ }^{27}$. CAT points out that protection of persons and groups which are marginalised and exposed to discrimination, including on the grounds of sexual orientation

${ }^{23}$ In the case of ICCPR, protection against discrimination is enhanced by the autonomous anti-discrimination clause contained in Article 26.

24 Toonen v. Australia, Communication No. 488/1992. In this case, HRC decided that the author of communication, who was of homosexual orientation, was discriminated against on the grounds of sex. However, it must be admitted that sexual orientation (like gender identity) are legally protected characteristics under ICCPR as "other status", which is confirmed by the subsequent practice of $\mathrm{HRC}$ where sexual orientation is an independent legally protected characteristic separated from discrimination on the grounds of sex. See also for example 'Discriminatory laws and practices and acts of violence against individuals based on their sexual orientation and gender identity. Report of the United Nations High Commissioner for Human Rights' (2011), A/HRC/19/41, para. 7.

${ }_{25}$ CESCR General Comment No. 14 (2000) The right to the highest attainable standard of health (Article 12), E/C.12/2000/4 at para. 18; CESCR General Comment No 15 (2002) The right to water, E/C.12/2002/11, para. 13.

26 CRC General Comment No. 3 (2003) HIV/AIDS and the rights of the child, CRC/ GC/2003/3, para. 8; General Comment No. 4 (2003), Adolescent health and development in the context of the Convention on the Rights of the Child, CRC/GC/2003/4, para. 6.

27 CEDAW General Recommendation No. 28 (2010) The core obligations of States parties under article 2, CEDAW/C/GC/28, para. 18. 
and gender identity, is an important aspect of counteracting torture and inhuman or degrading treatment ${ }^{28}$.

The recommendations of treaty bodies related to the protection of LGBT persons and addressed to Poland (Table 1) are a reflection of the evolution of the practice of the said bodies. The problems of discrimination on the grounds of sexual orientation and gender identity were taken up for the first time with reference to Poland in 2004 when $\mathrm{HRC}$ recommended adoption of legislation prohibiting discrimination on the grounds of sexual orientation in Polish law and organisation of training for law enforcement officials in order to make them sensitive to the rights of "sexual minorities" 29 . These recommendations were expanded upon considerably by HRC in $2010 .^{30}$ Likewise, CAT recommendations made in $2013^{31}$ were expanded upon compared to the former ones $(2007)^{32}$. So far, other treaty bodies have spoken only once on LGBT rights - in their concluding observations (CESCR 2009, CEDAW 2014, CRC 2015).

It should be pointed out that the adopted concluding observations lack adversarial recommendations. Therefore, we can conclude that the treaty bodies have promoted a certain "common standard" with reference to LGBT rights. This is confirmed by the recommendations which are recurrent in the output of a few treaty bodies. In particular, recommendations on the revision of law should be indicated. CESCR, HRC and CRC all pointed out that it is necessary to guarantee complex protection against discrimination at the statutory level. In the assessment of these bodies, the law, including the so-called Equal Treatment Act ${ }^{33}$ adopted in 2010, does not provide for comprehensive protection against discrimination, including on the grounds of sexual orientation ${ }^{34}$.

28 CAT General Comment No. 2 (2008) Implementation of article 2 by States parties, CAT/C/GC/2, para. 21.

${ }^{29}$ HRC 2004, para. 18. It should be observed that presently HRC, like other treaty bodies, departed from the use of the term "sexual minorities" and uses the term "LGBT persons", more: P. Geber and J. Gory, The UN Human Rights Committee and LGBT Rights: What is it doing? What could it be doing? 'Human Rights Law Review' 2014, p. 413.

30 HRC 2010, para. 8.

31 CAT 2013, para. 25.

32 CAT 2007, para. 20.

33 Ustawa z dnia 3 grudnia 2010 r. o wdrożeniu niektórych przepisów Unii Europejskiej w zakresie równego traktowania (Act of 3 December 2010 on the implementation of certain provisions of the European Union on equal treatment) Polish OJ 2010 No 254, item 1700.

34 CESCR 2009, para. 12; HRC 201, para. 5; CRC 2015, para. 16-17. 
Another recommendation concerning legal standards relates to the provision of criminal law protection against hate crimes motivated by homophobia. This recommendation was formulated for the first time in 2007 by $\mathrm{CAT}^{35}$, which repeated it in $2013^{36}$. The same recommendation was adopted by HRC in $2010^{37}$ and by CRC in $2015^{38}$. The recommendation to amend the Criminal Code and criminalise hate crimes against LGBT persons can be considered to be the most precise and most frequent recommendation, as it was made by three treaty bodies in the course of eight years. Despite a few legislative attempts made to introduce relevant amendments to the Criminal $\mathrm{Code}^{39}$, this recommendation has not presently been implemented.

A brand new recommendation concerning LGBT rights was formulated in 2017 by HRC which suggested "reviewing the legal status of same-sex couples and parents with a view to ensuring their enjoyment of the right to non-discrimination in law and in fact" ${ }^{* 0}$. Although HRC did not recommended that Poland introduce to its law any specific form of recognising same-sex couples such as marriage or registered partnership, it appears that any legal recognition is required in order to preserve the rights covered by ICCPR to same-sex partners and members of their families.

Other recommendations relate to law enforcement. We can notice that what individual committees are interested in is connected with the specific nature of the rights contained in a treaty monitored by them. CAT and HRC focus primarily on the counteraction of violence against LGBT persons. Both bodies regularly recommend organisation of training

35 CAT 2007, para. 20.

36 CAT 2013, para. 25.

37 HRC 2010, para. 8.

38 CRC 2015, para. 17.

39 See Poselski projekt ustawy o zmianie ustawy - Kodeks karny z dn. 18 kwietnia 2011 r. (Deputies' Bill on the amendment of the Criminal Code Act of 18 April 2011), Sejm paper no. 4253; Poselski projekt ustawy o zmianie ustawy - Kodeks karny z dn. 20 kwietnia 2012 r. (Deputies Bill on the amendment of the Criminal Code Act of 20 April 2012), Sejm paper no. 383; Poselski projekt ustawy o zmianie ustawy - Kodeks karny $z$ dn. 7 marca 2013 r. (Deputies' Bill on the amendment of the Criminal Code Act of 7 March 2013), Sejm paper no. 340; Poselski projekt ustawy o zmianie ustawy - Kodeks karny z dn. 3 lipca 2014 r. (Deputies Bill on the amendment of the Criminal Code Act of 3 July 2014), Sejm paper no. 2357.

40 HRC 2017, para 16. 
for law enforcement officials ${ }^{41}$ and prosecution of acts of violence against LGBT persons ${ }^{42}$. On the other hand, recommendations of CEDAW, CESCR and $C R C$ focus on the social aspects of counteracting discrimination on the grounds of sexual orientation and gender identity. All these bodies emphasised that it was necessary to start fighting homophobia and counteract dissemination of negative stereotypes about LGBT persons ${ }^{43}$. In particular, CEDAW expressed concern at the absence of measures to counter the campaign against "gender ideology" 44 . These recommendations are very general in character, since the committees have not defined what measures should be taken by the State (see Table 1 ).

\subsection{Case study 2. Women's reproductive rights}

Protection of reproductive health is one of the aspects of counteracting discrimination against women, which is confirmed by the provisions of the CEDAW Convention. It obliges the State party to take all appropriate measures to eliminate discrimination against women in health care in order to ensure, on the basis of equality of men and women, access to health care services, including those related to family planning (Article 12 para. 1). It also includes provisions on the rights to decide freely and responsibly on the number and spacing of their children and to have access to the information, education and means to enable them to exercise these rights (Article 16 para. 1e and Article $10 \mathrm{~h}$ ). From among the instruments under analysis, it is, apart from CRPD, the only mechanism in which protection of women's reproductive rights is directly incorporated into the provisions of the treaty.

In the case of the other treaty bodies, incorporation of the protection of women's reproductive rights into the monitoring process is the effect of the interpretation of treaty norms made by these bodies. HRC and CESCR are of the opinion that effective protection of women's reproductive rights is an element of the implementation of the principle of equal treatment of women and men contained in Article 3 of both Covenants. In the case of ICCPR, protection results primarily from the right to privacy guaranteed

CAT 2007, para. 20; CAT 2013, para. 25, HRC 2004, para. 18; HRC 2010, para. 8.

CAT 2013, para. 25; HRC 2010, para. 8.

CESCR 2009, para. 12; CRC 2015, para. 17.

CEDAW 2014, para. 22. 


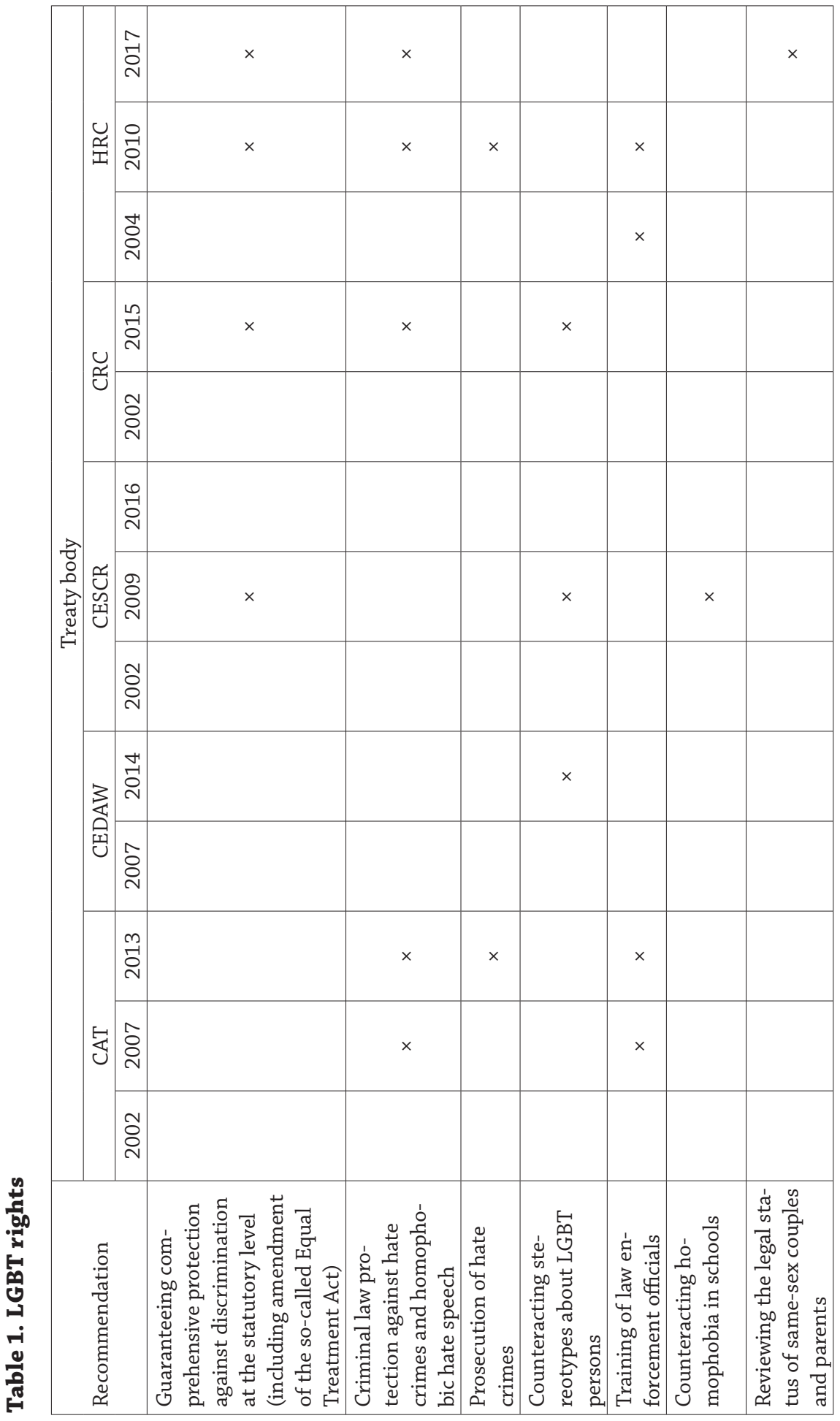


in Article $17^{45}$, whereas in the case of ICESCR, it results from the provisions of Article 12, where the right of everybody to the enjoyment of the highest attainable protection of physical and mental health is regulated ${ }^{46}$. Under the CRC Convention, the obligation to respect the reproductive health of children and adolescents, including girls, follows primarily from Article 24 (the right to the highest attainable standard of health) and Article 17 (the right to information) ${ }^{47}$. CAT practice relates to both impediments to access to legal abortion, as well as to other areas of reproductive health (e.g. forced sterilisation) $)^{48}$, which in CAT's opinion, like in the opinion of other human rights monitoring bodies ${ }^{49}$, can be a form of inhuman and degrading treatment, which was prohibited under the CAT Convention ${ }^{50}$.

All the treaty bodies mentioned above point out in their concluding observations addressed to Poland that there is a need to guarantee women access in practice to reproductive health services, including legal abortion (Table 2). In the case of CEDAW, HRC and CESCR, such recommendations are the effect of solid practice of the treaty bodies, and they are repeated in all concluding observations addressed to Poland in the last 15 years $^{51}$. In the case of CAT and CRC, we can clearly see that interest in the problems of women's reproductive rights has appeared in recent years. CAT made reference to the availability of abortion in Poland for the first time in $2013^{52}$, and CRC in $2015^{53}$

Four out of five treaty bodies, the recommendations of which were examined, did not restrict themselves to recommending that a State

45 HRC General Comment No. 28 (2000), Equality of rights between men and women, CCPR/C/21/Rev.1/Add.10, para. 20.

46 CESCR General Comment No. 16 (2005) The equal right of men and women to the enjoyment of all economic, social and cultural rights, para. 29.

47 CRC General Comment No. 4 (2003) Adolescent health and development in the context of the Convention on the Rights of the Child, para 28.

48 See A. Edwards, Violence against Women under International Human Rights Law, Cambridge University Press 2011, pp. 229-230.

49 See A. Zureick, (En)Gendering Suffering: Denial of Abortion as a Form of Cruel, Inhuman or Degrading Treatment, 'Fordham International Law Journal' 2015, vol. 38, pp. 99-140.

50 See generally R. Sifris, Reproductive Freedom, Torture and International Human Rights. Challenging the Masculinisation of Torture, Routledge, Oxon and New York 2014.

51 CEDAW 2007, para. 25; CEDAW 2014, para. 37; HRC 2004, para. 8; HRC 2010, para. 12; CESCR 2002, para. 50, CESCR 2009, para. 27.

52 CAT 2013, para. 23

53 CRC 2015, para. 39 
provides for effective access to abortion procedures in compliance with Polish legislation, but clearly stated that Poland should amend the Act on family planning, protection of the human foetus and the conditions permitting abortion ${ }^{54}$ and liberalise the conditions under which abortion is permitted ${ }^{55}$. We can say that these are the most radical statements by international control bodies in the area of human rights related to the admissibility of abortion in Poland, comparing, for example, the case law of the European Court of Human Rights, which is of the opinion that the State is obliged to ensure effective access to services in accordance with the conditions stipulated in the Act ${ }^{56}$, while admitting that the State should have a broad margin of appreciation when it comes to the definition of abortion admissibility limits ${ }^{57}$. At the same time, we can notice that in none of the bodies examined is the recommendation to liberalise the abortion law in Poland a recurring recommendation. CEDAW and CRC made such a recommendation in their latest concluding observations in 2014 and 2015, and therefore we can say that their position on the admissibility of abortion in Poland has become more radical. On the other hand, in the case of CESCR and HRC, we are dealing with a reversed practice the recommendation to liberalise the abortion law made by both treaty bodies in the previous years (2002 and 2004) was not repeated in the most recent recommendations. On the basis of available documents, it is not possible to indicate the reasons for this state of affairs. The analysis of the concluding observations of these treaty bodies, addressed in recent years to other States, indicates, however, that we cannot speak of any change of the interpretation of treaty obligations. Both $\mathrm{HRC}^{58}$ and $\mathrm{CESCR}^{59}$ are consistently of the opinion that a too restrictive abortion law and, in

54 Ustawa z dnia 7 stycznia 1993 r. o planowaniu rodziny, ochronie płodu ludzkiego i warunkach dopuszczalności przerywania ciąży (Act of 7 January 1993 on family planning, protection of the human foetus and the conditions permitting abortion), Polish OJ 1993, No 17, item 78 as amended.

55 CEDAW 2014, para. 37, CESCR 2002, para. 51; HRC 2004, para. 8; CRC 2015, para. 39.

56 For example Tysiąc v. Poland, no. 5410/03, 20.3.2007, at para. 116; R.R. v. Poland, no. 27617/04, 26.5.2011, para. 195; P. and S. v. Poland, no. 57375/08, 30.10.2012, para 100.

57 For example A.B. C. v. Ireland, no. 25579/05, 16.12.2010, para. 233.

58 For example HRC Malta (2014), CCPR/C/MLT/CO/2, para. 13, HRC Angola (2013), CCPR/C/AGO/CO/1, para. 13; Malawi (2014), CCPR/C/MWI/CO/1/Add.1, para. 9.

59 For example CESCR El Salvador (2014), E/C.12/SLV/CO/3-5, para. 22; CESCR Peru (2012), E/C.12/PER/CO/2-4, para. 21. 
particular, a complete ban and penalisation of abortion lead to the violation of women's rights stipulated in both treaties. They also called on Poland in their last concluding observations adopted in $2016^{60}$ and $2017^{61}$ to refrain from adopting any legislative reform that would amount to a retrogression of already restrictive legislation on women's access to safe legal abortion.

Another recommendation on legislative steps provides for the provision of an effective appeal measure from the doctor's decision to refuse abortion. Four out of five of the bodies examined made such recommendation in their concluding observations addressed to Poland ${ }^{62}$. In the opinion of these bodies, the right to object to a doctor's opinion or statement as introduced by the Act on Patient Rights and Patient Rights Ombudsman ${ }^{63}$ in order to implement the judgment of ECHR in the Tysiac vs. Poland case is not effective because of, inter alia, the too long time needed by the Medical Board to issue a decision ${ }^{64}$. As indicated by the bodies, the State is obliged to provide for such procedures so that the doctor's refusal, including use of the so-called conscientious objection clause, was not the obstacle to the service provided for in the legislation.

The other recommendations are about taking measures of a nonlegal nature. HRC and CEDAW regularly recommend that the government examine the number of illegal abortions and their consequences for the health and life of women ${ }^{65}$. Most of the bodies also recommend provision of access to subsidised contraception ${ }^{66}$ and sex education in

60 CESCR 2016, para. 46-47.

61 HRC 2017, para. 23-24.

62 CESCR 2009, para. 28; CESCR 2016, para 47; HRC 2010, para. 12, HRC 2017, para. 24; CAT 2013, para 23, CEDAW 2014, para. 36.

63 Ustawa z dnia 6 listopada 2008 r. o prawach pacjenta i Rzeczniku Praw Pacjenta (Act of 6 November 2008 on Patient Rights and Patient Rights Ombudsman), Polish OJ 2009, No. 52, item 417, as amended.

64 The same position is expressed by the Council of Europe's Committee of Ministers, which has not considered the judgment in Tysiac vs. Poland as enforced, http://www.coe. int/t/dghl/monitoring/execution/Reports/pendingCases_en.asp?CaseTitleOrNumber=Tysiac\&StateCode $=\&$ SectionCode [last accessed 23.3. 2016] .

65 CEDAW 2007, para 25, CEDAW 2014, para. 37, HRC 2004, para. 8, HRC 2010, para. 12.

66 CEDAW 2007, para 25; CEDAW 2014, para. 37; CESCR 2002, para 50; CESCR 2009, para. 27; CRC 2015, para. 39. 
schools ${ }^{67}$. CEDAW and CRC also point out that it is necessary to guarantee the reproductive rights of adolescent girls and boys ${ }^{68}$.

We can clearly see that the problems of women's reproductive rights are examined by all the bodies through the prism of the treaty they monitor. CEDAW, which has the broadest mandate on the human rights of women, formulates all the above mentioned recommendations in its concluding observations. HRC and CAT, on the other hand, are mainly interested in the availability of abortion in the context of the protection of the right to life and protection against inhuman and degrading treatment. CESCR and CRC focus on the protection of reproductive rights mainly with reference to the right to health and the right to education, i.e. availability of contraception and sex education. CRC, for reasons of its mandate, examines these problems through the prism of health protection of adolescent girls and boys.

The analysis of the recommendations reveals that we can speak of a certain "common standard" formulated by the treaty bodies with reference to the protection of women's reproductive health in Poland. Among the concluding observations analysed, there are no adversarial recommendations. Most of them are recurrent and have been formulated by at least two bodies. Some differences can be pointed out, but these are connected with the degree of precision or detail. For example, CESCR urged the State "to implement adequate programmes in sexual and reproductive education in national school curricula" ${ }^{69}$, while CRC recommended "to expand the scope of the compulsory Family Life Education to provide a comprehensive, age-appropriate education on sexual and reproductive health, including information on family planning and contraceptives, the dangers of early pregnancy and the prevention and treatment of sexually transmitted diseases"70. Sometimes there are linguistic differences only, which affect the degree of persuasion rather than the message itself. For example, referring to the problem of the conscientious objective clause, HRC expressed concern that the regulations governing it "are often inappropriately applied" ${ }^{71}$, while CEDAW made reference to "the extensive

67 CEDAW 2007, para. 25; CEDAW 2014, para. 37; CESCR 2002, para. 50; CESCR 2009, para. 31; CRC 2002, para. 43, CRC 2015, para. 39.

68 CEDAW 2007, para. 25; CEDAW 2014, para. 36; CRC 2002, para. 43, CRC 2015, para. 39.

69 CESCR 2009, para. 31.

70 CRC 2014, para. 39.

71 HRC 2010, para. 12. 
use, or abuse, by medical personnel of the conscientious objection clause"72 (see Table 2).

\section{Implementation of the recommendations of treaty bodies on equality and non-discrimination by Poland}

By taking concluding observations regarding equality and nondiscrimination in Poland as an example, we can identify nine main types of recommendations. These are:

1. Recommendations to undertake legislative steps, i.e. introduction of new regulations into the legal order, e.g. incorporation of the definition of human trafficking into the Criminal Code ${ }^{73}$, or amendment of the existing regulations, e.g. the recommendation to amend the so-called Equal Treatment Act ${ }^{74}$.

2. Recommendations to establish a relevant institutional framework, e.g. strengthening the mandate of the Government Plenipotentiary for Equal Treatment and allocation of a relevant budget $^{75}$.

3. Recommendations related to the practice of law application, e.g. recommendation to ensure effective enforcement of the laws declaring illegal parties or organisations which promote or incite racial discrimination ${ }^{76}$.

4. Recommendations on the adoption and implementation of relevant programmes, strategies and policies, e.g. recommendation to accelerate adoption of a programme for the Roma community in Poland for 2014-2020 ${ }^{77}$ or inclusion of actions for counteracting gender stereotypes, especially those that perpetuate sexual violence, as a key priority, into the National Action Plan for Equal Treatment $^{78}$.

CEDAW 2014, para. 36.

CESCR 2002, para. 46, CEDAW 2007, para. 21.

HRC 2010, para. 5; CEDAW 2014, para. 11, CRC 2015, para. 17.

CEDAW 2014, para. 17.

CERD 2014, para. 10.

CERD 2014, para. 13.

CEDAW 2014, para. 23. 


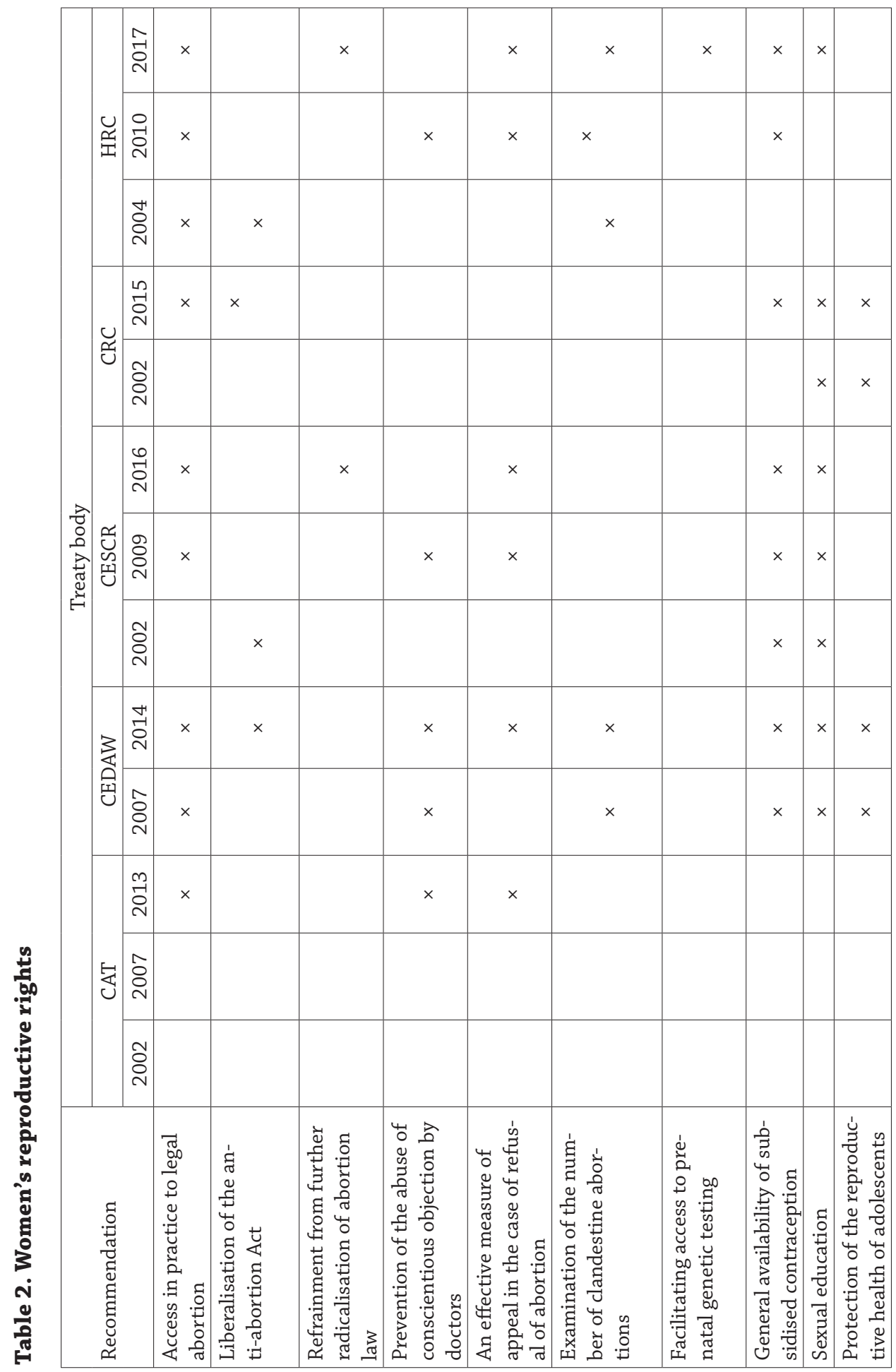


5. Recommendations on the implementation of training for law enforcement officials, e.g. training for judges, prosecutors, police, border guards or social workers, preparing them for work in gender-sensitive ways with victims of human trafficking ${ }^{79}$.

6. Recommendations on the implementation of promotional and social campaigns, e.g. to enhance awareness-raising programmes among the general public on intercultural dialogue and tolerance and on the history and culture of ethnic and national minorities ${ }^{80}$.

7. Recommendations to investigate certain phenomena or collect data, e.g. recommendations to estimate the number of illegal abortions and examine the phenomenon of underground abortions ${ }^{81}$.

8. Recommendations to ratify international instruments, e.g. International Convention on the Protection of the Rights of All Migrant Workers and Members of Their Families ${ }^{82}$.

9. Recommendations to implement decisions made at the UN conferences on counteracting discrimination, e.g. the Durban Declaration and Programme of Action ${ }^{83}$ or the Beijing Declaration and Platform for Action ${ }^{84}$.

Determination of the extent to which all these recommendations have been implemented is beyond the scope of this study. Only recommendations to initiate a legislative process have been selected for the purposes of this research. Comparison of the present status of Polish law with the recommendations made by the committees in 2000-2017 enables one to precisely define the number of recommendations which have been implemented and obtain an answer to the question about the extent to which recommendations of treaty bodies on equality and non-discrimination are reflected in Polish law.

An analysis of the material led to identification of sixteen recommendations to undertake legislative steps (Table 3). When this number is compared to the number of all recommendations in total, we can notice that recommendations on the legal status constitute a relatively

79

80

81

CEDAW 2014, para. 27.

CERD 2014, para. 12.

CEDAW 2007, para. 25, CEDAW 2014, para. 37, HRC 2004, para. 8, HRC 2010, para. 12 .

${ }^{82}$ CERD 2014, para. 16.

83 CERD 2014, para. 17

84 CEDAW 2014, para. 46. 
small percentage of the recommendation. Based on this data only, we could say that the committees have few reservations about the condition of Polish law and recommend primarily work on law application or in a non-legal area. However, it should be noted that some recommendations relate to legislative steps that are fundamental to the elimination of discrimination, for instance those concerning the so-called Equal Treatment $\mathrm{Act}^{85}$. In the opinion of the treaty bodies, the present deficits of this Act make it impossible to effectively counteract discrimination. This group of recommendations also includes the recommendation on the liberalisation of the anti-abortion law. Undoubtedly, changes in this area would be of key importance for the improvement of the level of protection of women's reproductive health in Poland.

An analysis of the recommendations to start a legislative process leads to some conclusions. Firstly, most of the legal changes have been recommended by at least two treaty bodies. This confirms the argument that the treaty bodies formulate a "common standard" in the area of equality and non-discrimination. The recommendations adopted by one body only include either recommendations which have already been implemented (such as introduction of legal prohibition of sexual harassment, penalisation of instigation to racial hatred) or recommendations related to relatively new legal instruments, such as the Quota Act of 2011.

Secondly, half of the recommendations were related to criminal material or process law. They identified certain kinds of crimes committed on the grounds of discrimination on different grounds (e.g. penalisation of hate speech against LGBT persons, introduction of the crime of human trafficking into the Criminal Code), prosecution of such crimes (recognition of racial motivation as an aggravating circumstance) or introduction of criminal law protection measures for victims (police restraining order).

Thirdly, only one recommendation related to the general legal framework connected with counteraction of discrimination (recommendation to amend the so-called Equal Treatment Act). The other recommendations related to legal measures taken for the benefit of specific groups. Two recommendations related to the rights of LGBT persons (introduction of criminal law protection against hate crimes and homophobic hate speech, review of the legal status of sex-same couples), two recommendations related to the counteraction of racial discrimination (penalisation of instigation to racial hatred and recognition of racial motivation as

85 Supra n. 32. 
an aggravating circumstance in the Criminal Code), and one concerned persons with disabilities (voting rights). All the other recommendations related to the problem of women's equality. This means that over $70 \%$ of the recommendations related to legal instruments which could be used to eliminate different forms of discrimination against women. We can conclude that in the opinion of the treaty bodies, gender equality has been the most problematic area, requiring the undertaking of legislative steps. The recommendations of the treaty bodies reveal how many areas required and continue to require the legislator's attention in order to eliminate discrimination in different spheres of women's lives - from personal safety, i.e. introduction of different legal measures to counteract violence against women and protect victims of violence, through protection of reproductive health, to participation in public life (recommendation to introduce the zip system to the Quota Act).

Fourthly, based on the analysed recommendations, we can argue that the extent to which treaty recommendations have been implemented by Poland is small. Out of sixteen recommendations identified, only four have been implemented ${ }^{86}$. This means that over $70 \%$ of the recommendations have not yet been implemented. The amendments which have been made relate to criminal law and labour and social protection law. In 2009, an Act extending the definition of the crime of fascism promotion and incitement for racial hatred contained in Article 256 of the Criminal Code was passed ${ }^{87}$. In the explanatory report to the Act, reference was made to Article 20 para. 2 ICCPR, and it was pointed out that the amendment implements "many international agreements", while there was no reference to the concluding observations of the treaty bodies ${ }^{88}$. In 2010, a definition of trafficking in

86 CESCR recommendation on the adoption of an Act on equal status of women and men made in 2002 was found to be implemented partially since certain regulations related to that area have been contained in the so-called Equal Treatment Act.

87 Ustawa z dnia 5 listopada 2009 r. o zmianie ustawy - Kodeks karny, ustawy - Kodeks postępowania karnego, ustawy - Kodeks karny wykonawczy, ustawy Kodeks karny skarbowy oraz niektórych innych ustaw (Act of 5 November 2009 on the amendment of the Criminal Code Act, Criminal Proceedings Act, Executive Criminal Code Act, Criminal and Fiscal Code Act and some other Acts), Polish OJ 2009, No. 206, item 1589.

88 Explanatory report to the draft Act, Sejm paper no. 1288, http://orka.sejm.gov. pl/Druki6ka.nsf/wgdruku/1288 [last accessed 23.3.2016]. 
human beings was incorporated into the Criminal Code ${ }^{89}$. The amendment was aimed primarily to adapt Polish law to the so-called Palermo Protocol ${ }^{90}$ and Council of Europe Convention on Action against Trafficking in Human Beings ${ }^{91}$. However, in the explanatory report to the Act, no reference was made to the concluding observations of the treaty bodies or to Article 6 of the CEDAW Convention, which obliges States to take legislative steps to fight trafficking in women ${ }^{92}$.

The amendments made to labour and social insurance law relate to the area of gender equality. In 2012, an amendment to the Act on pensions and disability pensions paid from the Social Insurance Fund ${ }^{93}$ was passed, which introduced provisions for gradual introduction of an equal retirement age for men and women, i.e. 67 years. As pointed out by the legislator, the amendment was aimed, among other things, at adapting Polish law to EU standards ${ }^{94}$. This reform was abolished by a law in 2016 which reintroduced an unequal retirement age for women (60 years) and men (65 years) ${ }^{95}$. Introduction of the definition of sexual harassment to the labour code in $2008^{96}$, as well as other regulations aimed

89 Ustawa z dnia 20 maja 2010 r. o zmianie ustawy - Kodeks karny, ustawy o Policji, ustawy - Przepisy wprowadzające Kodeks karny oraz ustawy - Kodeks postępowania karnego (Act of 20 May 2010 on the amendment of the Criminal Code Act, Act on Police, Regulations introducing the Criminal Code Act and Criminal Proceedings Code Act), Polish OJ 2010, No. 98, item 626.

90 Protocol to Prevent, Suppress and Punish Trafficking in Persons, Especially Women and Children, supplementing the United Nations Convention against Transnational Organised Crime, 15.11.2000, available at https://www.unodc.org/unodc/treaties/CTOC/.

91 Council of Europe Convention on Action against Trafficking in Human Beings, 16.5.2005, available at http://www.coe.int/en/web/conventions/full-list/-/conventions/ treaty/197.

92 Explanatory report to the draft Act, Sejm paper no. 2387, http://orka.sejm.gov. pl/Druki6ka.nsf/wgdruku/2387 [last accessed 23.3.2016].

93 Ustawa z dnia 11 maja 2012 r. o zmianie ustawy o emeryturach i rentach z Funduszu Ubezpieczeń Społecznych oraz niektórych innych ustaw (Act of 11 May 2012 amending the Act on pensions and disability pensions paid from the Social Insurance Fund and certain other Acts), Polish OJ 2012, item 637.

94 Explanatory report to the draft Act. Sejm paper no. 329, http://www.sejm.gov. pl/sejm7.nsf/PrzebiegProc.xsp?nr=329 [last accessed 23.3.2016].

95 Ustawa z dnia 16 listopada 2016 r. o zmianie ustawy o emeryturach i rentach z Funduszu Ubezpieczeń Społecznych oraz niektórych innych ustaw (Act of 16 November 2016 on the amendment of Act on pensions), Polish OJ 2017, item 38.

96 Ustawa z dnia 21 listopada 2008 r. o zmianie ustawy - Kodeks pracy (Act of 21 November 2008 on the amendment of the Criminal Code Act), Polish OJ 2008, No. 223, 
at the implementation of the principle of equal treatment of women and men in employment, were also influenced by EU law. As we can clearly see, in the case of the recommendations of treaty bodies which have been implemented, the legislative action was mainly motivated by the need to adjust Polish law to EU law or to other international standards. Bearing in mind that concluding observations are of a non-binding nature, it is symptomatic that they were not even referred to during the legislative process. It seems that a lack of sufficient knowledge combined with the weak authority of UN human rights bodies are the main reasons.

Table 3. Implementation of the recommendations to undertake legislative steps.

\begin{tabular}{|c|c|c|}
\hline Recommendation & Treaty body & Implementation \\
\hline $\begin{array}{l}\text { Amendment of the so-called equal } \\
\text { treatment Act }\end{array}$ & $\begin{array}{l}\text { HRC 2010, CEDAW 2014, CRC } \\
\text { 2015, CESCR 2016, HRC } 2017\end{array}$ & NO \\
\hline $\begin{array}{l}\text { Identification of domestic violence as } \\
\text { a crime in the Criminal Code and the } \\
\text { Act on counteracting family violence }\end{array}$ & $\begin{array}{l}\text { CESCR 2009, CAT 2013, CEDAW } \\
2014\end{array}$ & NO \\
\hline $\begin{array}{l}\text { Identification of marital rape as a } \\
\text { crime in the Criminal Code and the } \\
\text { Act on counteracting family violence }\end{array}$ & $\begin{array}{l}\text { CESCR 2009, CAT 2013, CEDAW } \\
\text { 2014, CESCR } 2016\end{array}$ & NO \\
\hline $\begin{array}{l}\text { Introduction of a police restraining } \\
\text { order to protect victims of domestic } \\
\text { violence }\end{array}$ & $\begin{array}{l}\text { HRC 2004, CEDAW 2007, HRC } \\
\text { 2010, HRC } 2017\end{array}$ & NO \\
\hline $\begin{array}{l}\text { Guarantee of an effective legal mea- } \\
\text { sure in the case of refusal of abortion } \\
\text { (amendment of the Act on patient's } \\
\text { rights) }\end{array}$ & $\begin{array}{l}\text { CESCR 2009, HRC 2010, CAT } \\
\text { 2013, CEDAW 2014, CESCR 2016, } \\
\text { HRC } 2017\end{array}$ & NO \\
\hline $\begin{array}{l}\text { Incorporation of the definition of } \\
\text { trafficking in human beings into the } \\
\text { Criminal Code }\end{array}$ & CESCR 2002, CEDAW 2007 & YES \\
\hline $\begin{array}{l}\text { Introduction of equal retirement age } \\
\text { for women and men }\end{array}$ & $\begin{array}{l}\text { CESCR 2002, CESCR 2009, CEDAW } \\
2007\end{array}$ & YES/NOa \\
\hline $\begin{array}{l}\text { Incorporation of the zip system to } \\
\text { the Act on quotas }\end{array}$ & CEDAW 2014 & NO \\
\hline Liberalisation of the abortion Act & $\begin{array}{l}\text { CESCR 2002, HRC 2004, CEDAW } \\
\text { 2014, CRC } 2015\end{array}$ & NO \\
\hline $\begin{array}{l}\text { Legislation of an Act on equal status } \\
\text { of women and men }\end{array}$ & CESCR 2002 & $\mathrm{YES} / \mathrm{NO}^{\mathrm{b}}$ \\
\hline $\begin{array}{l}\text { Introduction of legal prohibition of } \\
\text { sexual harassment }\end{array}$ & CESCR 2002 & YES \\
\hline
\end{tabular}

item 1460. 
Concluding observations of the UN human rights...

\begin{tabular}{|l|l|l|}
\hline \multicolumn{1}{|c|}{ Recommendation } & \multicolumn{1}{|c|}{ Treaty body } & Implementation \\
\hline $\begin{array}{l}\text { Expansion of penalisation of instiga- } \\
\text { tion to racial hatred }\end{array}$ & CERD 2009 & YES \\
\hline $\begin{array}{l}\text { Recognition of racial motivation as } \\
\text { an aggravating circumstance (amend- } \\
\text { ment of the Criminal Code) }\end{array}$ & CERD 2014 & NO \\
\hline $\begin{array}{l}\text { Criminal law protection against hate } \\
\text { crimes and homophobic hate speech } \\
- \text { amendment of the Criminal Code }\end{array}$ & $\begin{array}{l}\text { CAT 2007, HRC 2010, CRC 2015, } \\
\text { CRC 2017 }\end{array}$ & NO \\
\hline $\begin{array}{l}\text { Reviewing the legal status of same- } \\
\text { sex couples and parents }\end{array}$ & HRC 2017 & NO \\
\hline $\begin{array}{l}\text { Reviewing legislation restraining the } \\
\text { voting rights of persons with mental } \\
\text { and intellectual disabilities }\end{array}$ & HRC 2017 & NO \\
\hline
\end{tabular}

a This recommendation was implemented by the Act of 2012, which was abolished in 2016 (see supra notes No. 93 and 95).

b This recommendation can be recognised as fulfilled to some extent by provisions of the Equal Treatment Act.

\section{Conclusion}

Treaty bodies have mechanisms which make it possible to regularly and comprehensively control the observance of human rights by the State. The issues related to the principle of equality and non-discrimination are particularly present in their work. As indicated, all the committees which monitor the obligations assumed by Poland (HRC, CESCR, CERD, CEDAW, CAT, CRC, CRPD) formulate in their concluding observations recommendations to take specific actions to implement this principle.

The analysis of the recommendations related to the protection of the rights of LGBT persons and protection of women's reproductive rights reveals that we can speak of a certain "common standard" formulated by the treaty bodies. Although each one of them provide an autonomous interpretation of specific treaty obligations, many recommendations formulated about the issues under analysis overlap. Only a few recommendations were made by one treaty body only, and in many cases, the recommendations were made by a few treaty bodies. Some of the recommendations are recurrent, i.e. a given treaty body regularly formulates them in its subsequent concluding observations addressed to Poland. None of the recommendations were contradictory, i.e. none 
of the committees formulated a recommendation to start an action contrary to that recommended by it or another treaty body earlier.

The study on the impact of the recommendations of the treatybodies on Polish law in the area of equality and non-discrimination indicates that only about $30 \%$ of the recommendations to start a specific legislative process have been implemented, but this action was mainly aimed at the implementation of EU standards or implementation of other international obligations. The majority of the recommendations of the treaty bodies have not yet been implemented. Nearly $70 \%$ of these recommendations concern legal measures for the elimination of discrimination against women. These recommendations relate to different areas of human rights - from participation in public life, through the protection of reproductive health, to counteracting different forms of violence against women. It may be concluded that although the UN human rights treaty bodies have provided Poland with constant and convergent recommendations over the last 17 years, the country has remained highly resistant, particularly in the field of gender equality.

\section{Bibliography}

1. Bayefsky A., The Principle of Equality or Non-Discrimination in International Law, 'Human Rights Quarterly' 1990, no 1-2

2. Caytas J.D., Women's Reproductive Rights as a Political Price of Post-communist Transformation in Poland, 'Amsterdam Law Forum' 2013, no. 2

3. Edwards A., Violence against Women under International Human Rights Law, Cambridge University Press 2011

4. Geber P. and Gory J., The UN Human Rights Committee and LGBT Rights: What is it doing? What could it be doing? 'Human Rights Law Review' 2014

5. Heyns Ch. and Viljoen F., The Impact of the United Nations Human Rights Treaties on the Domestic Level, Martinus Nijhoff Publishers, The HagueLondon 2002

6. Krommendijk J., The (In)effectiveness of UN Human Rights Treaty Body Recommendations, 'Netherlands Quarterly of Human Rights' 2015, no 2

7. Sifris R., Reproductive Freedom, Torture and International Human Rights. Challenging the Masculinisation of Torture, Routledge, Oxon and New York 2014

8. Vandenhole W., Non-Discrimination and Equality in the View of the UN Human Rights Treaty Bodies, Intersentia, Antwerpen-Oxford 2005 
9. Warso Z. and Bodnar A., 'Legal Study on Homophobia and Discrimination on Grounds of Sexual Orientation and Gender Identity. Poland. January 2014 Update' FRA Country Report

10. Zureick A., (En)Gendering Suffering: Denial of Abortion as a Form of Cruel, Inhuman or Degrading Treatment, 'Fordham International Law Journal' 2015, vol. 38 